\title{
Impact of Sous Vide Cooking on Nutritional Quality of Meat
}

\author{
María Victoria Aviles ${ }^{1}$, Elisa Naef ${ }^{1}$, Liliana Lound ${ }^{1}$ and Daniela Oliveraa ${ }^{2,3 *}$ \\ ${ }^{1}$ Facultad de Bromatología, Universidad Nacional de Entre Ríos, Argentina \\ ${ }^{2}$ Centro de Investigación y Desarrollo en Criotecnología de Alimentos (CIDCA), Argentina \\ ${ }^{3}$ Facultad de Ciencias Veterinarias, Argentina
}

Submission: September 12, 2020; Published: September 25, 2020

*Corresponding author: Daniela Olivera, Centro de Investigación y Desarrollo en Criotecnología de Alimentos (CIDCA), CCT La Plata-CONICET - UNLP CIC, Argentina. 47 y 116, 1900 La Plata, Argentina

\begin{abstract}
Cooking becomes the meat more digestible, eating, and palatable. However, heat treatment can cause undesirable nutritional changes in meat, such as loss of minerals and vitamins, oxidation of lipids and changes in some segments of the protein fraction. The use of sous vide processing technology, which refers to cooking vacuum-sealed food in heat-stable plastic pouches under precisely monitored conditions, represents an interesting cooking alternative in terms of retains its natural sensory qualities of meat along with the nutritional value. In this paper, the research on the effect of sous vide cooking of meat on its nutritional quality is reviewed.
\end{abstract}

Keywords: Minerals content; Bioaccessibility; Vacuum cooking

\section{Introduction}

Meat and meat products are essential components of eating habits in developed countries. Meat is a basic part of a healthy and balanced diet due to its nutritional wealth. It contains valuable nutrients for human health [1]. It is an important source of protein (> 20\% average on a wet basis) with high digestibility (> 95\%). Moreover, it is also a vital source of B vitamins, zinc, selenium, heme-iron, and phosphorus, among others [2].

Meat and meat products are generally cooked before consumption. Cooking is essential to destroy foodborne pathogens and spoilage microorganisms, ensure microbial safety and achieve sensory quality in meat. Cooking becomes the meat more digestible and eating $[3,4]$. Generally, the consumer chooses a cooking method that produces meat products of high quality in terms of tenderness, appearance, and flavor [5]. Furthermore, cooking also has an important effect on nutritional properties $[3,6]$. Heat treatment can cause undesirable changes in meat, such as loss of minerals and vitamins, oxidation of lipids and changes in some segments of the protein fraction [3]. Likewise, due to the high temperatures of traditional processes (frying, roasting or grilling), numerous Maillard reaction products are created with a positive impact on the palatability of meat products, but the harmful impact on human health $[7,8]$.
Sous vide cooking (sous vide in French means "vacuum") is presented as an alternative to traditional methods, with less drastic process conditions. This technique was originally developed for the catering industry since it allows the handling of prepared foods after heat treatment without risk of microbial contamination [9]. In sous vide cooking the food is placed in a bag, then the air is removed, and the package is sealed. The packaged foods are then cooked in a temperature range of 50 to $90^{\circ} \mathrm{C}$, with corresponding periods. Immediately after heating, the products should be cooled to $3^{\circ} \mathrm{C}$ or less $[9,10]$.

Sous vide cooking has several advantages: it increases shelf life by eliminating the risk of contamination during storage; inhibits oxidation of off-flavours and prevents evaporation losses of flavour volatiles and moisture during cooking $[10,11]$.

For sous vide cooking of meat, the process temperature ranges from $50{ }^{\circ} \mathrm{C}$ to $90^{\circ} \mathrm{C}$ and generally involves several hours of heating $[11,12,13]$.

Several studies report the benefits in tenderness of vacuumheated meats compared to traditional cooking methods $[12,13]$. As well as the nutritional benefits of this cooking method due to the less drastic process conditions and because the packaging of 
the product prevents the leaching of nutrients. Despite this, few available studies quantify this superior nutritional quality of meat mentioned $[10,14]$.

Regarding the effect of the cooking method on the vitamin content, fat-soluble vitamins, are less heat-labile than watersoluble vitamins. Although they are susceptible to destruction at high temperatures in the presence of oxygen since the cooking methods at higher temperatures cause oxidative reactions producing free radicals and oxidative products, which can hinder the nutritional properties of the fat-soluble vitamins [15]. In this sense, [16] studied the retention of the B vitamins in meat cooked by the sous vide method. They informed that this method preserved vitamins liable to oxidation better than traditional cooking, but this advantage was removed by storage and following reheating. In this report the authors compare their results with traditional methods obtained from bibliography. More recent, Ayub and Ahmad [17] informed that sous vide treatment caused lower cooking losses than traditional cooking and this parameter normally correlate with the juiciness of the meat, and consequently more retention of vitamins occurs.

On the other hand, the effect of sous vide cooking on the mineral retention of meat was studied by some researchers recently. Da Silva et al. [18] evaluated the impact of heating processes on the bioaccessibility of minerals in bovine liver samples by use of in vitro method. The authors comparing a sous vide heating with heating in water boiling. Both cooking treatments of bovine liver encourage the increase of the bioaccessibility of $\mathrm{Ca}, \mathrm{Cu}$, $\mathrm{Fe}, \mathrm{K}$ and $\mathrm{Mg}$, except for $\mathrm{Zn}$ where the effect is the contrary (the bioaccessibility decrease). Also, their results show that the sous vide method provides higher bioaccessibility of these minerals than water boiling cooking, except for $\mathrm{K}$, that both methods present equivalent values.

Likewise, Modzelewska Kapitułaa et al. [19] studied the effect of sous vide and steam cooking, on minerals $(\mathrm{Ca}, \mathrm{Cu}, \mathrm{Fe}$, $\mathrm{Zn}, \mathrm{Mg}, \mathrm{Mn}, \mathrm{K}, \mathrm{Na}$ ) contents and fatty acid composition in beef semimembranosus muscle from Bulls. The authors reported that steam cooked beef showed higher $\mathrm{Ca}, \mathrm{Fe}, \mathrm{Zn}$ and $\mathrm{Cu}$ contents and lower contents of $\mathrm{Na}$ and $\mathrm{K}$ than sous vide samples. Also, the content of Mg and Mn in steam-cooked and sous vide samples was like that noted in raw meat. Regarding fatty acids, sous vide beef had a lower proportion of polyunsaturated fatty acids, including $n-3$, than steam-cooked beef, but a similar $n-6 / n-3$ ratio.

On the other hand, Bhat el al. [14] performed the in vitro gastrointestinal digestive simulation of vacuum cooked beef. The authors observed significantly higher values of some minerals such as $\mathrm{Cu}, \mathrm{K}, \mathrm{Mg}$ and $\mathrm{S}$ for the samples processed under vacuum compared to those cooked with the traditional method. Besides, they report increased digestibility, soluble protein, and free amino acids for sous vide cooking, inferring that more enzymatic hydrolysis and digestion had occurred in the vacuum processed samples.
Last, in sous vide cooking meat the lack of high temperatures on the surface and the absence of surface dehydration to the far lower formation of Maillard reaction compounds $[7,8]$ This is processing technology offers the potential to reduce the risks associated with cooking of meat, due that low temperature cooking with longer times to reduce the formation of polyaromatic hydrocarbons, heterocyclic aromatic amines, and acrylamides during cooking of meat $[8,20]$.

\section{Conclusion}

Sous vide cooking has the potential to reduce the quality losses in meat and meat products as compared to traditional cooking technology because of its low-temperature application. This method improves the sensory characteristics of the meat, such as texture and the juiciness, reduce the cooking losses, without impairing the quality of meat proteins and lipid oxidative stability.

\section{Acknowledgements}

The authors acknowledge the support from Consejo Nacional de Investigaciones Científicas y Técnicas, CONICET, and Universidad Nacional de La Plata, Argentina. .

\section{References}

1. Biesalski HK (2005) Meat as a component of a healthy diet-are there any risks or benefits if meat is avoided in the diet? Meat science 70(3): 509-524.

2. Bohrer BM (2017) Review: Nutrient density and nutritional value of meat products and non-meat foods high in protein. Trends in Food Science and Technology 65: 103-112.

3. Tornberg E (2005) Effects of heat on meat proteins. Implications on structure and quality of meat products. Meat Science 70(3): 493-508.

4. Ureta M, Olivera D, Segura L, Salvadori V, Goñi S (2019) Kinetic modelling of meat color evolution during heating. Latin American Applied Research 49: 131-136.

5. Mcafee AJ, Mcsorley EM, Cuskelly GJ, Moss BW, Wallace JMW, et al. (2010) Red meat consumption: An overview of the risks and benefits. Meat Science 84(1): 1-13.

6. Domingues R, Borrajo P, Lorenzo J (2015) The effect of cooking methods on nutritional value of foal meat. Journal of Food Composition and Analysis 43: 61-67.

7. Roldán M, Ruiz J, Sánchez del Pulgar J, Pérez-Palacios T, Antequera T (2015) Volatile compound profile of sous-vide cooked lamb loins at different temperature-time combinations. Meat Science 100: 52-57.

8. Ruiz-Carrascal J, Roldan M, Refolio F, Perez-Palacios T, Antequera $T$ (2019) Sous-vide cooking of meat: A Maillarized approach. International Journal of Gastronomy and Food Science 16: 100138.

9. Baldwin DE (2012) Sous vide cooking: A review. International Journal of Gastronomy and Food Science 1: 15-30.

10. Creed PG, Reeve W (1998) Principles and applications of sous vide processed foods. In: Sous Vide and Cook-Chill Processing for the Food Industry (edited by S. Ghazala). Gaithersburg, MD: Aspen. Pp. 25-56.

11. Mortensen LM, Frost MB, Skibsted LH, Risbo J (2012) Effect of time and temperature on sensory properties in low-temperature long-time sous-vide cooking of beef. Journal of Culinary Science and Technology 10: 75-90. 
12. Dominguez-Hernandeza E, Salasevicieneb A, Ertbjerg P (2018) Lowtemperature long-time cooking of meat: Eating quality and underlying Mechanisms. Meat Science 143: 104-113.

13. Vaudagna S, Sanchez G, Neira MS, Insani EM, Picallo AB, et al. (2002) Sous vide cooked beef muscles: Effects of low temperature-long time (LT-LT) treatments on their quality characteristics and storage stability. International Journal of Food Science and Technology 37(4): 425-441.

14. Bhat Z, Morton J, Zhang X, Mason S, Bekhit A (2020) Sous-vide cooking improves the quality and in-vitro digestibility of Semitendinosus from culled dairy cows. Food Research International 127: 108708.

15. Suleman R, Wang Z, Aadil M, Hui T, Hopkins D, et al. (2020) Effect of cooking on the nutritive quality, sensory properties, and safety of lamb meat: Current challenges and future prospects. Meat Science 167: 108172 .

16. Watier B, Belliot JP (1991) Vitamines et technologie industrielle recente. Cahiers Nutrition. Dietetique 26: 23-26.
17. Ayub H, Ahmad A (2019) Physiochemical changes in sous-vide and conventionally cooked meat. International Journal of Gastronomy and Food Science 17: 100145

18. da Silva FLF, de Lima JPS, Melo LS, da Silva YSM, Gouveia ST, et al. (2017) Comparison between boiling and vacuum cooking (sous vide) in the bioaccessibility of minerals in bovine liver samples. Food Research International 100: 566-571.

19. Modzelewska Kapitułaa M, Pietrzak Fiećkob R, Tkacza K, Draszanowskac A, Więk A (2019) Influence of sous vide and steam cooking on mineral contents, fatty acid composition and tenderness of Semimembranosus muscle from Holstein-Friesian bulls. Meat Science 157: 107877.

20. Gibis M (2016) Heterocyclic Aromatic Amines in Cooked Meat Products: Causes, Formation, occurrence, and Risk Assessment. Comprehensive Reviews in Food Science and Food Safety 15: 269-302.

\section{Your next submission with Juniper Publishers} will reach you the below assets

- Quality Editorial service

- Swift Peer Review

- Reprints availability

- E-prints Service

- Manuscript Podcast for convenient understanding

- Global attainment for your research

- Manuscript accessibility in different formats

( Pdf, E-pub, Full Text, Audio)

- Unceasing customer service

Track the below URL for one-step submission https://juniperpublishers.com/online-submission.php 